\title{
Determining the optimal nitrogen rate for summer maize in China by integrating agronomic, economic, and environmental aspects
}

\author{
G. L. Wang ${ }^{1, *}$, Y. L. Ye ${ }^{2, *}$, X. P. Chen ${ }^{1}$, and Z. L. Cui ${ }^{1}$ \\ ${ }^{1}$ Center for Resources, Environment and Food Security, China Agricultural University, Beijing, 100193, China \\ ${ }^{2}$ College of Resources and Environmental Sciences, Henan Agricultural University, Zhengzhou, 450000, China \\ *These authors contributed equally to this work.
}

Correspondence to: Z. L. Cui (cuizl@ cau.edu.cn)

Received: 26 November 2013 - Published in Biogeosciences Discuss.: 14 February 2014

Revised: 23 April 2014 - Accepted: 25 April 2014 - Published: 11 June 2014

\begin{abstract}
The concept of high yield with a goal of minimum environmental cost has become widely accepted. However, the trade-offs and complex linkages among agronomic, economic, and environmental factors are not yet well understood. In this study, reactive nitrogen $\left(\mathrm{N}_{\mathrm{r}}\right)$ losses were estimated using an empirical model, and an economic indicator and an evaluation model were used to account for the environmental costs of $\mathrm{N}$ fertilizer production and use. The minimum $\mathrm{N}$ rate to achieve the maximum yield benefit (agronomically optimal $\mathrm{N}$ rate), maximum economic benefit (economically optimal $\mathrm{N}$ rate: economic benefit was defined as yield benefit minus $\mathrm{N}$ fertilizer cost), and maximum net benefit (ecologically optimal $\mathrm{N}$ rate: net benefit was defined as yield benefit minus $\mathrm{N}$ fertilizer and environmental costs) were estimated based on 91 on-farm experiment sites with five $\mathrm{N} \mathrm{lev-}$ els for summer maize production on the North China Plain. Across all experimental sites, the agronomically, economically, and ecologically optimal $\mathrm{N}$ rates $\left(\mathrm{N}_{\mathrm{agr}}, \mathrm{N}_{\mathrm{eco}}\right.$, and $\mathrm{N}_{\mathrm{ecl}}$, respectively) averaged 289,237 , and $171 \mathrm{~kg} \mathrm{~N} \mathrm{ha}^{-1}$, respectively. $\mathrm{N}_{\mathrm{ecl}}$ management increased net benefit by $53 \%$ with a $46 \%$ decrease in total environmental costs, and a $51 \%$ decrease in $\mathrm{N}_{\mathrm{r}}$ loss intensity from $\mathrm{N}$ fertilizer use $(47,65$, and $38 \%$ for $\mathrm{N}_{2} \mathrm{O}$ emission, $\mathrm{N}$ leaching, and $\mathrm{NH}_{3}$ volatilization, respectively) and maintained grain yield, compared with $\mathrm{N}_{\mathrm{agr}}$ management. Compared with $\mathrm{N}_{\mathrm{eco}}$ management, $\mathrm{N}_{\mathrm{ecl}}$ increased net benefit by $12 \%$, with a $31 \%$ decrease in total environmental costs and a $33 \%$ decrease in $\mathrm{N}_{\mathrm{r}}$ loss intensity from $\mathrm{N}$ fertilizer use, and maintained economic benefit and grain yield. No differences in $\mathrm{N}_{\mathrm{ecl}}$ were observed between soil types or years, but significant variation among counties was revealed. $\mathrm{N}_{\mathrm{ecl}}$ increased with the increase in $\mathrm{N}$-derived
\end{abstract}

yield with an $R^{2}$ of 0.83 . In conclusion, $\mathrm{N}_{\mathrm{ecl}}$ was primarily affected by $\mathrm{N}$-derived yield and could enhance profitability as well as reduce $\mathrm{N}_{\mathrm{r}}$ losses associated with the maize grain yield.

\section{Introduction}

Nitrogen (N) is a crucial nutrient that requires careful management in intensive cropping systems because of its diverse beneficial and detrimental effects (Ju and Christie, 2011). Worldwide, $\mathrm{N}$ has contributed to higher yields and economic returns to farmers, but it has also been estimated that more than $50 \%$ of applied $\mathrm{N}$ remains unutilized, leading to losses of billions of US dollars (Raun and Johnson, 1999). Meanwhile, the massive amounts of $\mathrm{N}$ that have leached into water bodies, or been lost into the atmosphere through ammonia volatilization or nitrification-denitrification (Zhu and Chen, 2002), have contributed to various environmental problems, such as the greenhouse effect, eutrophication, and soil acidification (Davidson, 2009; Guo et al., 2010; Ju et al., 2009; Reay et al., 2012; Zhang et al., 1996). In the future, to double crop production, global $\mathrm{N}$ fertilizer use will increase by 110 $130 \%$ from 2000 to 2050 (Cassman and Pingali, 1995; Galloway et al., 2004; Tilman et al., 2001). Therefore, it is necessary to resolve the contradictions among grain yield, economic benefit, and environmental cost, forming solutions to improve $\mathrm{N}$ management strategies agronomically, economically, and environmentally.

In China, the pursuit of high grain yields has been the top priority in policy and in practice (Meng et al., 2012). Thus, 
current research on improving $\mathrm{N}$ management strategies has recommended $\mathrm{N}$ application rates according to input-output relationships (such as yield-response curves), with the soilcrop system regarded to some extent as a "black box" due to our poor understanding of the complex $\mathrm{N}$ cycling processes occurring in soils (Ju and Christie, 2011). With this approach, although notable success has been achieved in terms of maximizing yield, the overuse of $\mathrm{N}$ fertilization has often been encouraged (Cassman et al., 2002; Drinkwater and Snapp, 2007). For example, a typical $\mathrm{N}$ application rate was recommended as around $263 \mathrm{~kg} \mathrm{Nha}^{-1}$ for summer maize farmers on the North China Plain (Cui et al., 2005), whereas the results of region-wide experiments have demonstrated that $\mathrm{N}$ rates could be reduced to $158 \mathrm{~kg} \mathrm{Nha}^{-1}$ without yield losses (Cui et al., 2008).

In the past few decades, $\mathrm{N}$ application rates have been further optimized based on combined economic benefits, effects of $\mathrm{N}$ use efficiency, and environmental effects (Liang et al., 2008; Xia and Yan, 2011b). Some studies have linked crop yields and fertilizer to economic indicators, with the recommended $\mathrm{N}$ rate being calculated as the $\mathrm{N}$ fertilizer rate when the price ratio of $\mathrm{N}$ fertilizer to crop yield is equal to the first derivative of the yield response function (Zhu, 2006). Wang et al. (2013) indicated a rate of $169 \mathrm{~kg} \mathrm{Nha}^{-1}$ for maize cultivation with an agronomic $\mathrm{N}$ efficiency of $23 \mathrm{~kg} \mathrm{~kg}^{-1}$, $77 \%$ higher than the $\mathrm{N}$ practices of typical farmers. Liu et al. (2013) recommended an optimal $\mathrm{N}$ rate of $110 \mathrm{~kg} \mathrm{~N} \mathrm{ha}^{-1}$, with a threshold of nitrate- $\mathrm{N}$ content in the $0-90 \mathrm{~cm}$ soil layer to mitigate the risk of nitrate leaching. In these studies, however, environmental loads were simply reflected by $\mathrm{N}$ use efficiency and prime cost, without detailed consideration of information on environmental performance, such as nitrate pollution in water related to $\mathrm{N}$ leaching and $\mathrm{NH}_{3}$ volatilization, greenhouse effects related to $\mathrm{N}_{2} \mathrm{O}$ emission, and soil acidification related to $\mathrm{NH}_{3}$ volatilization.

In intensive agricultural cropping systems, the soil $\mathrm{N}$ cycle becomes complex after the application of $\mathrm{N}$ fertilizer (Cui et al., 2013a; Kim et al., 2012), which provides substrates both for crop $\mathrm{N}$ uptake and for the soil microorganisms responsible for different reactive $\mathrm{N}\left(\mathrm{N}_{\mathrm{r}}\right)$ losses (Kim et al., 2012). However, increasing the $\mathrm{N}$ application rate cannot promise a sustained increase in crop or economic productivity because of diminishing returns (Cassman et al., 2003), whereas the increases in $\mathrm{N}$ rate lead to concurrent environmental impacts (Cui et al., 2013a; McSwiney and Robertson, 2005).

Previously, in studies on optimal $\mathrm{N}$ rates, environmental effects and agronomic effects have been notably disconnected, although both are clearly linked to $\mathrm{N}$ fertilizer inputs (Cui et al., 2013b). Here, we hypothesize that the optimal $\mathrm{N}$ rate integrating agronomic, economic, and environmental aspects could maximize grain yield and economic benefits while minimizing $\mathrm{N}_{\mathrm{r}}$ loss intensity (unit, $\mathrm{kg} \mathrm{N} \mathrm{Mg}^{-1}$ grain yield). In this study, an economic indicator and an evaluation model were used to account for the environmental effects of $\mathrm{N}$ fertilizer production and use (Zhang et al., 2012; Xia and Yan, 2012). The response curves of N-derived yield, economic benefit, and net benefit to the $\mathrm{N}$ application rate were provided to assess three $\mathrm{N}$ rates, defined as the agronomic, economic, and ecological $\mathrm{N}$ rates, respectively (detail described below). Our objectives were to compare grain yield, benefit, and $\mathrm{N}_{\mathrm{r}}$ losses among the agronomic, economic, and ecological $\mathrm{N}$ rates, and to clarify the variations in the ecological $\mathrm{N}$ rate.

\section{Materials and methods}

\subsection{Experimental design}

The experiment was conducted on the NCP (North China Plain), which is a major maize-production region. The climate of the study area is warm, subhumid continental monsoon with cold winters and hot summers. Maize is planted at the end of June and matures in early October. The growing degree days (GDD) from maize planting to maturity measure $1500-1700$ GDD. Annual precipitation is $500-700 \mathrm{~mm}$, with $\sim 70 \%$ of rainfall occurring during the maize growing season (Ye et al., 2011). No irrigation water is supplied for maize production in this region.

In total, 91 on-farm experiment sites (i.e., in farmers' fields) were used for maize production from 2008 to 2009 in 12 counties of Henan Province, including Hebi, Jiaozuo, Kaifeng, Luoyang, Nanyang, Pingdingshan, Shanmenxia, Shangqiu, Xinxiang, Zhenzhou, Zhoukou, and Zhumadian counties (Supplement Fig. 1). These experimental sites were located between 31 and $36^{\circ} \mathrm{N}$ latitude and 110 and $117^{\circ} \mathrm{E}$ longitude, and included $80 \%$ of the counties in this region. All experimental sites received five $\mathrm{N}$ treatments with three replicates: $0 \mathrm{~N}$ control $\left(\mathrm{N}_{0}\right)$, median $\mathrm{N}$ rate $(\mathrm{MN}), 50 \%$ median $\mathrm{N}$ rate $(50 \% \mathrm{MN}), 150 \%$ median $\mathrm{N}$ rate $(150 \% \mathrm{MN})$, and $200 \%$ median $\mathrm{N}$ rate $(200 \% \mathrm{MN})$. The $\mathrm{MN}$ was derived from agronomists' recommendations based on experience and target economic yields (1.1 times the average yield of the past 5 years), which varied by site. Across all sites, the MN averaged $232 \mathrm{~kg} \mathrm{Nha}^{-1}\left(120-360 \mathrm{~kg} \mathrm{Nha}^{-1}\right.$; Supplement Table 1).

The experiments were conducted in winter wheat-summer maize rotation systems, and new experimental sites were selected each year. Approximately one third of the $\mathrm{N}$ fertilizer was applied at pre-sowing, and two thirds were applied at around the six-leaf stage. $\mathrm{N}$ was distributed as urea by hand with plowing, during pre-sowing, and with deep placement at the six-leaf stage. Soil types included mainly fluvo-aquic soil, cinnamon soil, and red clay (Zhang, 2002).

Plot sizes measured $>40 \mathrm{~m}^{2}$. Based on soil phosphorus (P) and potassium $(\mathrm{K})$ levels, all plots received appropriate amounts of triple superphosphate $\left(75-150 \mathrm{~kg} \mathrm{P}_{2} \mathrm{O}_{5} \mathrm{ha}^{-1}\right)$ and potassium chloride $\left(75-150 \mathrm{~kg} \mathrm{~K}_{2} \mathrm{O} \mathrm{ha}^{-1}\right.$ ) pre-sowing. As the typical fertilizer method in this area (Zhang et al., 2013; Liu et al., 2010), no organic manure was applied at any 
experimental site. Each field experiment was managed using the individual producer's current crop management practices, except for necessary experimental treatments, such as fertilizer application and grain yield assessment at harvest. Different varieties of maize hybrids were used among experimental sites, with the varieties being selected by the respective farmers. Weeds were well controlled and no obvious water or pest stresses were observed during the maize growing season. Summer maize was planted with a row spacing of $50-70 \mathrm{~cm}$ immediately without tillage after winter wheat harvests at the end of June and was harvested in early October with straw returning. At harvest, at least $8 \mathrm{~m}^{2}$ (two rows, $\sim 8 \mathrm{~m}$ long) in the middle of each plot were harvested to determine grain and stover biomass weights.

\subsection{Estimating the agronomically, economically, and ecologically optimal $\mathrm{N}$ rates}

\subsubsection{Estimating the agronomically optimal $\mathrm{N}$ rate}

The agronomically optimal $\mathrm{N}$ rate $\left(\mathrm{N}_{\mathrm{agr}}, \mathrm{kg} \mathrm{N} \mathrm{ha}^{-1}\right)$ was determined by calculating the first derivative of the $\mathrm{N}$-derived grain yield response curve to the $\mathrm{N}$ application rate (Eq. 2) (Bullock and Bullock, 1994), which was described as a quadratic function (Eq. 1) (Cassman and Plant, 1992; Dobermann et al., 2000)

$$
\begin{aligned}
Y_{\mathrm{N}} & =Y-Y_{0}=\beta \cdot \mathrm{N}+\alpha \cdot \mathrm{N}^{2} \\
N_{\mathrm{agr}} & =-\beta / 2 \cdot \alpha
\end{aligned}
$$

where $Y_{\mathrm{N}}$ is the increase in grain yield response with the addition of $\mathrm{N}$ fertilizer application ( $\mathrm{N}$-derived yield, $\mathrm{Mg} \mathrm{ha}^{-1}$ ), $Y$ and $Y_{0}$ are the grain yields $\left(\mathrm{Mg} \mathrm{ha}^{-1}\right)$ with and without applied $\mathrm{N}$, respectively, $\mathrm{N}$ is the $\mathrm{N}$ fertilizer application rate $\left(\mathrm{kg} \mathrm{Nha}^{-1}\right.$ ), and $\alpha$ and $\beta$ are regression coefficients.

\subsubsection{Estimating the economically optimal $\mathrm{N}$ rate}

The economically optimum $\mathrm{N}$ rate $\left(\mathrm{N}_{\mathrm{eco}}, \mathrm{kg} \mathrm{N} \mathrm{ha}^{-1}\right)$ was defined as the $\mathrm{N}$ fertilizer rate when the price ratio of $\mathrm{N}$ fertilizer to maize yield was equal to the first derivative of the yield response function (Neeteson and Wadman, 1987; Sawyer et al., 2006), that is, the marginal cost of fertilization $\mathrm{N}$ is equivalent to the marginal revenue of maize production. From the first derivative of the economic benefit function (Eq. 3), $\mathrm{N}_{\mathrm{eco}}$ was estimated by Eq. (4):

$$
\begin{aligned}
\mathrm{EB} & =B_{Y}-C_{\mathrm{N}}=b \cdot \mathrm{N}+a \cdot \mathrm{N}^{2} \\
N_{\mathrm{eco}} & =-b / 2 \cdot a
\end{aligned}
$$

where EB is economic benefit $\left(\$ \mathrm{ha}^{-1}\right)$ and $B_{Y}$ and $C_{\mathrm{N}}$ refer to the $\mathrm{N}$-derived yield benefit and the cost of $\mathrm{N}$ fertilizer $\left(\$ \mathrm{ha}^{-1}\right)$, respectively. We averaged the price of $\mathrm{N}$ fertilizer for maize as $710 \$$ ton $^{-1}$ from an investigation of county fertilizer dealers in this experimental region from 2008 to 2009. The average maize price adopted of $360 \$$ ton $^{-1}$ was released by the Chinese government (http://www.sdpc.gov.cn/). $a$ and $b$ are regression coefficients.

\subsubsection{Estimating the ecologically optimal $\mathrm{N}$ rate}

Considering yield benefit, the cost of $\mathrm{N}$ fertilizer, and environmental costs, the ecologically optimal $\mathrm{N}$ rate was defined as the $\mathrm{N}$ fertilizer rate with maximum net benefit, which equals the revenue of $\mathrm{N}$-derived maize production minus the costs associated with $\mathrm{N}$ fertilizer and the cost to the environment, described as follows:

$$
\begin{aligned}
\mathrm{NB} & =B_{Y}-C_{\mathrm{N}}-C_{\mathrm{e}}=A \cdot N+B \cdot \mathrm{N}^{2} \\
\mathrm{~N}_{\mathrm{ecl}} & =-B / 2 \cdot A
\end{aligned}
$$

where NB is the net benefit $\left(\$ \mathrm{ha}^{-1}\right)$ and $C_{\mathrm{e}}$ are the environmental costs associated with $\mathrm{N}$ fertilizer production and use, which is quantitatively estimated using a damage cost method in this study (Moomaw and Birch, 2005; Xia and Yan, 2012). Here, the environmental damage cost $\left(C_{\mathrm{e}}\right.$, $\$ \mathrm{ha}^{-1}$ ) consisted of the costs of greenhouse gas damage to air resources, eutrophication damage to water resources, and acidification damage to soil resources. Detailed descriptions of how to estimate these various environmental costs are shown in Eqs. (7)-(9).

$$
C_{\mathrm{gw}}=\left[\left(\mathrm{N}_{2} \mathrm{O}-\mathrm{N} \times 44 / 28 \times 298\right)+\left(\mathrm{N} \times \mathrm{EF}_{1}\right)\right] \times P_{\mathrm{g}}
$$

where $C_{\mathrm{gw}}$ is the global warming cost of greenhouse gas damage to air resources associated with $\mathrm{N}$ fertilizer production and use, $\mathrm{N}_{2} \mathrm{O}-\mathrm{N}$ is the $\mathrm{N}$ lost by $\mathrm{N}_{2} \mathrm{O}$ emissions $\left(\mathrm{kg} \mathrm{Nha}^{-1}\right)$ from $\mathrm{N}$ fertilizer use, 44/28 is a factor to convert $\mathrm{kg} \mathrm{N}$ to $\mathrm{kg} \mathrm{N}_{2} \mathrm{O}, 298$ is the $\mathrm{CO}_{2}$ equivalent on a 100 year timescale for the global warming potential of $1 \mathrm{~kg} \mathrm{~N}_{2} \mathrm{O}$ (Forster et al., 2007), $\mathrm{EF}_{1}$ as $8.2 \mathrm{~kg} \mathrm{CO}_{2}$ eq kg-1 is the $\mathrm{CO}_{2}$ equivalent for global warming potential of $\mathrm{CO}_{2}, \mathrm{CH}_{4}$ and $\mathrm{N}_{2} \mathrm{O}$ emissions from per $\mathrm{kgN}$ fertilizer production (Yue, 2013; Zhang et al., 2012), and $P_{\mathrm{g}}$ is the market price of $\mathrm{CO}_{2}$, set at $\$ 23.8$ ton $^{-1}$ for 2008 (Xia and Yan, 2011a).

$$
\begin{aligned}
C_{\mathrm{eu}} & =\left[\left(0.42 \times \mathrm{NO}_{3}-\mathrm{N}\right)+\left(0.33 \times \mathrm{NH}_{3}-\mathrm{N} \times 17 / 14\right)\right. \\
& \left.+\left(\mathrm{N} \times \mathrm{EF}_{2}\right)\right] \times P_{\mathrm{e}}
\end{aligned}
$$

where $C_{\mathrm{eu}}$ is the cost of eutrophication damage to water resources, $\mathrm{NO}_{3}-\mathrm{N}$ and $\mathrm{NH}_{3}-\mathrm{N}$ are the $\mathrm{N}$ lost by $\mathrm{NO}_{3}-\mathrm{N}$ leaching and ammonia volatilization $\left(\mathrm{kg} \mathrm{N} \mathrm{ha}^{-1}\right)$ from $\mathrm{N}$ fertilizer use, respectively, 0.42 and 0.33 are the $\mathrm{PO}_{4}$ equivalent eutrophication for $\mathrm{NO}_{3}-\mathrm{N}$ and $\mathrm{NH}_{3}$, respectively (Goedkoop, $1995), 17 / 14$ is a factor to convert $\mathrm{kg} \mathrm{N}$ to $\mathrm{kg} \mathrm{NH}_{3}, \mathrm{EF}_{2}$ as $3.0 \times 10^{-3} \mathrm{~kg} \mathrm{PO}_{4}$ eq kg${ }^{-1}$ is the $\mathrm{PO}_{4}$ equivalent eutrophication of per $\mathrm{kg} \mathrm{N}$ fertilizer production (Yue, 2013; Zhang et al., 2012), and $P_{\mathrm{e}}$ is the equivalent cost of $\mathrm{PO}_{4}$, set at $\$ 0.6 \mathrm{~kg}^{-1}$ in eutrophication (Xia and Yan, 2011a).

$$
C_{\text {acid }}=\left[\left(\mathrm{NH}_{3}-\mathrm{N} \times 17 / 44 \times 1.88\right)+\left(\mathrm{N} \times \mathrm{EF}_{3}\right)\right] \times P_{\mathrm{a}}
$$

where $C_{\text {acid }}$ is the cost of acidification damage to soil resources, $\mathrm{NH}_{3}-\mathrm{N}$ is the $\mathrm{N}$ lost by ammonia volatilization 
$\left(\mathrm{kg} \mathrm{N} \mathrm{ha}^{-1}\right.$ ) from $\mathrm{N}$ fertilizer use, $17 / 14$ is a factor to convert $\mathrm{kg} \mathrm{N}$ to $\mathrm{kg} \mathrm{NH}_{3}, 1.88$ is the $\mathrm{SO}_{2}$ equivalent acidification for $\mathrm{NH}_{3}$ (Goedkoop, 1995), $\mathrm{EF}_{3}$ as $2.5 \times 10^{-2} \mathrm{~kg} \mathrm{SO}_{2} \mathrm{eq} \mathrm{kg}{ }^{-1}$, is the $\mathrm{SO}_{2}$ equivalent acidification of per $\mathrm{kg} \mathrm{N}$ fertilizer production (Yue, 2013; Zhang et al., 2012), and $P_{\mathrm{a}}$ is the cost per $\mathrm{kg}$ of the $\mathrm{SO}_{2}$ equivalent, as $\$ 0.82 \mathrm{~kg}^{-1}$ in acidification (Xia and Yan, 2011a).

In this study, the losses of $\mathrm{N}_{2} \mathrm{O}-\mathrm{N}, \mathrm{NO}_{3}-\mathrm{N}$, and $\mathrm{NH}_{3}-$ $\mathrm{N}$ described above in Eqs. (7)-(9) were estimated with the

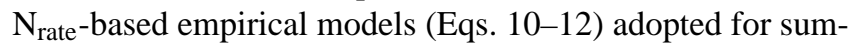
mer maize in the study region (Cui et al., 2013a).

$$
\begin{aligned}
& \mathrm{N}_{2} \mathrm{O}-\mathrm{N}=0.48 \times \exp (0.0058 \times \mathrm{N}) \\
& \mathrm{NO}_{3}-\mathrm{N}=4.46 \times \exp (0.0094 \times \mathrm{N}) \\
& \mathrm{NH}_{3}-\mathrm{N}=0.24 \times \mathrm{N}+1.30
\end{aligned}
$$

\subsection{Data analysis}

To establish the N-derived yield, economic benefit, and net benefit response curves to the $\mathrm{N}$ rate, $t$ tests were used to examine the significance of the regression coefficients and intercepts in fitted parametric models, and the coefficients of determination $\left(R^{2}\right)$ for fitted parametric models were used as the criteria for model selection: models with higher $R^{2}$ values were selected. A one-way analysis of variance (ANOVA; Guarda et al., 2004) was used to compare the mean $\mathrm{N}$ rate, grain yield, benefit, and loss among $\mathrm{N}_{\text {agr }}, \mathrm{N}_{\mathrm{eco}}$, and $\mathrm{N}_{\mathrm{ecl}}$ managements, and among different soil types, years, and counties, based on the least significant difference (LSD) at a $5 \%$ level of probability. These statistical analyses were conducted using SPSS 13.0 (SPSS Inc., Chicago, IL, USA) and SigmaPlot 10.0 (Systat, San Jose, CA, USA).

\section{Results}

\subsection{Comparison of agronomically, economically, and ecologically optimal $\mathbf{N}$ rates}

Across all 91 experimental sites, the grain yield for the $\mathrm{N}_{0}$ treatment averaged $6.6 \mathrm{Mgha}^{-1}$ and varied from 3.2 to $10.8 \mathrm{Mg} \mathrm{ha}^{-1}$ (Supplement Table 1 and Table 1). The MN across all 91 fields averaged $231 \mathrm{~kg} \mathrm{Nha}^{-1}$ and varied from 120 to $240 \mathrm{~kg} \mathrm{Nha}^{-1}$, and the grain yield averaged $8.4 \mathrm{Mg} \mathrm{ha}^{-1}$ and varied from 5.4 to $11.9 \mathrm{Mg} \mathrm{ha}^{-1}$. Under the $50 \% \mathrm{MN}$ treatment (average $115 \mathrm{~kg} \mathrm{Nha}^{-1}$ ), grain yield decreased by $8.5 \%$, while it decreased by $7.5 \%$ under the $200 \% \mathrm{MN}$ treatment (average $462 \mathrm{~kg} \mathrm{~N} \mathrm{ha}^{-1}$ ). These results indicated that both overuse and deficits in $\mathrm{N}$ application resulted in lower grain yields.

Across all sites and $\mathrm{N}$ treatments, the $\mathrm{N}$-derived grain yield averaged $1.5 \mathrm{Mg} \mathrm{ha}^{-1}$ in response to additional $\mathrm{N}$ application, varying from -0.5 to $4.1 \mathrm{Mg} \mathrm{ha}^{-1}$, while the economic benefit averaged $318 \$ \mathrm{ha}^{-1}$ and varied from -513 to $1319 \$ \mathrm{ha}^{-1}$. The environmental cost from $\mathrm{N}$ fertilizer production and use averaged $265 \$ \mathrm{ha}^{-1}$, including 89, 41 and
$135 \$ \mathrm{ha}^{-1}$ for the costs of global warming, eutrophication, and soil acidification, respectively (Supplement Table 1 and Fig. 1). Over all sites and $\mathrm{N}$ treatments, the net benefit averaged $53 \$ \mathrm{ha}^{-1}$ and varied from -998 to $1119 \$ \mathrm{ha}^{-1}$.

For all 91 sites, the N-derived yield, and economic and net benefit responses to increasing the amount of $\mathrm{N}$ applied were preferably simulated by quadratic functions (Figs. 1 and $2 ; p<0.05)$. The minimum $\mathrm{N}$ rate to achieve the maximum yield benefit $\left(\mathrm{N}_{\mathrm{agr}}\right)$, maximum economic benefit $\left(\mathrm{N}_{\mathrm{eco}}\right)$, and maximum net benefit $\left(\mathrm{N}_{\mathrm{ecl}}\right)$ averaged 289 , 237, and $171 \mathrm{~kg} \mathrm{Nha}^{-1}$, respectively (Tables 2 and 3). Compared with $\mathrm{N}_{\text {agr }}$ management, the net benefit for $\mathrm{N}_{\mathrm{ecl}}$ management increased by $53 \%$ from 200 to $306 \$$ ha $^{-1}$ with a $0.3 \mathrm{Mgha}^{-1}$ decrease in grain yield while maintaining an economic benefit at $445 \$ \mathrm{ha}^{-1}$. Correspondingly, the total environment costs decreased by $46 \%$, the total $\mathrm{N}_{\mathrm{r}}$ loss intensity decreased by $51 \%$, and $\mathrm{N}_{2} \mathrm{O}$ emission, $\mathrm{N}$ leaching, and $\mathrm{NH}_{3}$ volatilization were reduced by 47,65 , and $38 \%$, respectively. No significant differences were observed in grain yield, or economic or net benefit between $\mathrm{N}_{\mathrm{ecl}}$ and $\mathrm{N}_{\mathrm{eco}}$ management, while total environment costs and total $\mathrm{N}_{\mathrm{r}}$ loss intensity were reduced by 31 and $33 \%$, including 29,44 , and $25 \%$ for $\mathrm{N}_{2} \mathrm{O}$ emission, $\mathrm{N}$ leaching, and $\mathrm{NH}_{3}$ volatilization, respectively. These results indicated that applying an appropriate $\mathrm{N}$ rate could significantly decrease environmental costs and $\mathrm{N}_{\mathrm{r}}$ losses while maintaining both maximum grain yield and farm profitability.

\subsection{Variation in the ecologically optimal $\mathrm{N}$ rate}

Across all 91 experimental sites, the $\mathrm{N}_{\mathrm{ecl}}$ ranged widely from 45 to $272 \mathrm{~kg} \mathrm{Nha}^{-1}$ with a coefficient of variation (CV) of $33 \%$ (Supplement Table 2). No differences were observed in $\mathrm{N}_{\mathrm{ecl}}$ among different soil types, with 175, 163, and $172 \mathrm{~kg} \mathrm{Nha}^{-1}$ for fluvo-aquic soil, cinnamon soil, and red clay, respectively. The year also did not significantly affect $\mathrm{N}_{\mathrm{ecl}}$, which measured 180 and $166 \mathrm{~kg} \mathrm{Nha}^{-1}$ in 2008 and 2009, respectively. Significant differences in $\mathrm{N}_{\mathrm{ecl}}$ occurred among counties (Fig. 3a). For example, the lowest $\mathrm{N}_{\mathrm{ecl}}$ was $133 \mathrm{~kg} \mathrm{~N} \mathrm{ha}^{-1}$ in Nanyang County, whereas the $\mathrm{N}_{\mathrm{ecl}}$ was $68 \%$ higher at $224 \mathrm{~kg} \mathrm{~N} \mathrm{ha}^{-1}$ in Shangqiu County. Similarly, large differences were observed among sites in each county (Supplement Table 2). For example, in Hebi County, the lowest $\mathrm{N}_{\mathrm{ecl}}$ was $47 \mathrm{~kg} \mathrm{~N}^{-1}$ at site 1 , compared with the highest of $222 \mathrm{~kg} \mathrm{~N} \mathrm{ha}^{-1}$ at site 10 .

Correspondingly, grain yield, control yield, and N-derived yield showed no differences among different soil types or years, but were significantly affected by county (Fig. 3bd). For example, in Pinddingshan County, grain yield and control yield were the lowest at 5.8 and $3.9 \mathrm{Mg} \mathrm{ha}^{-1}, 61 \%$ and $49 \%$, respectively, lower than those in Hebi County. The $\mathrm{N}$-derived yield in Nanyang County measured $1.0 \mathrm{Mg} \mathrm{ha}^{-1}$, while the highest, in Zhumadian County, showed a $164 \%$ increase at $2.7 \mathrm{Mg} \mathrm{ha}^{-1}$. Such notable variations were also observed among sites in each county (Supplement Table 2). 
Table 1. Summary statistics of the $\mathrm{N}$ rate and grain yield over 91 sites in 12 counties in Henan Province for maize production in China from 2008 to $2009 . \mathrm{MN}$ is the median $\mathrm{N}$ rate.

\begin{tabular}{lrrrrrrrr}
\hline Treatment & N rate & \multicolumn{7}{c}{ Grain yield $\left(\mathrm{Mg} \mathrm{ha}^{-1}\right)$} \\
\cline { 3 - 9 } & $\mathrm{kg} \mathrm{Nha}^{-1}$ & Mean & $\mathrm{SD}$ & Minimum & Maximum & Median & $25 \% Q$ & $75 \% Q$ \\
\hline N0 & 0 & 6.6 & 1.6 & 3.2 & 10.8 & 6.7 & 5.6 & 7.7 \\
$50 \% \mathrm{MN}$ & 115 & 7.7 & 1.5 & 3.8 & 11.6 & 7.9 & 6.5 & 8.8 \\
$\mathrm{MN}$ & 231 & 8.4 & 1.3 & 5.4 & 11.9 & 8.5 & 7.4 & 9.3 \\
$150 \% \mathrm{MN}$ & 346 & 8.2 & 1.5 & 4.7 & 12.0 & 8.4 & 7.1 & 9.2 \\
$200 \% \mathrm{MN}$ & 462 & 7.8 & 1.4 & 4.3 & 11.3 & 7.8 & 6.7 & 8.9 \\
\hline
\end{tabular}
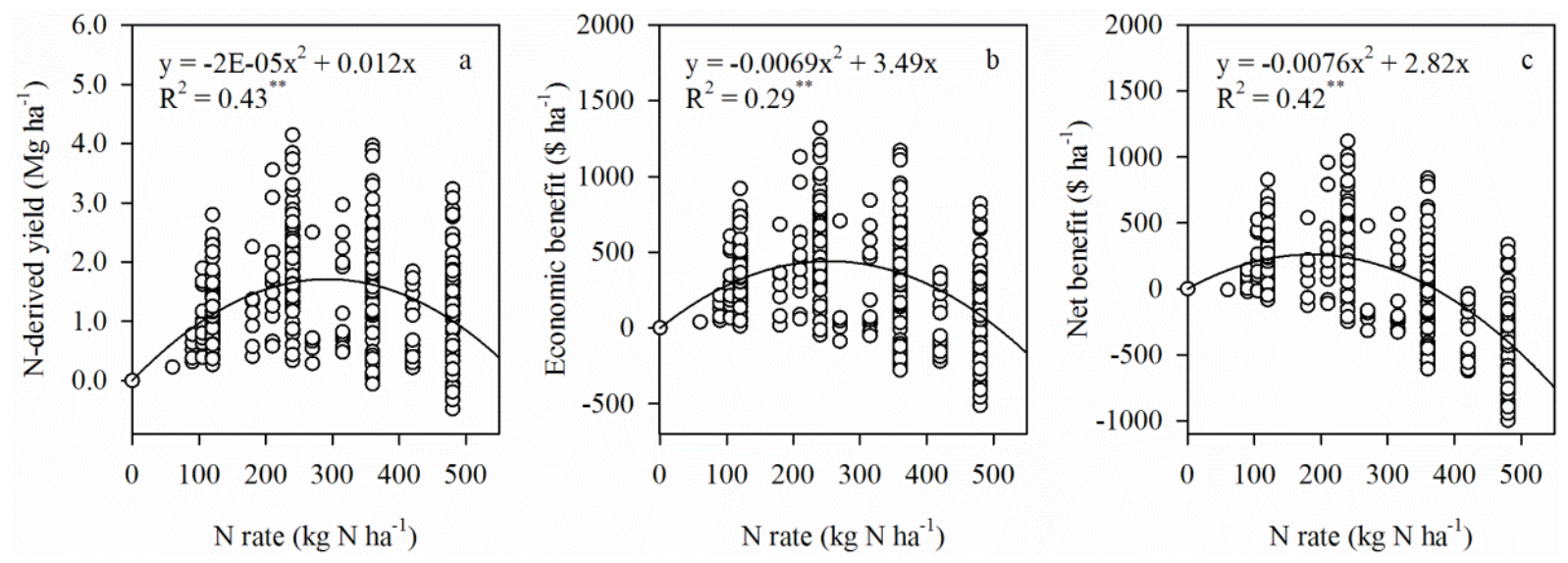

Figure 1. Relationships between the $\mathrm{N}$ rate and $\mathrm{N}$-derived yield (a), economic benefit (b), and net benefit (c) over 91 sites in 12 counties in Henan Province for maize production in China from 2008 to 2009 . ** Significant at $p<0.05$.

For example, within $\mathrm{N}_{\mathrm{ecl}}$ in Hebi County, the lowest $\mathrm{N}$ derived yield was $0.22 \mathrm{Mgha}^{-1}$ at site 1 , while the highest was $2.23 \mathrm{Mg} \mathrm{ha}^{-1}$ at site 11 .

No significant correlation was observed between grain yield and $\mathrm{N}_{\mathrm{ecl}}$, despite the large variations in both (Fig. $4 \mathrm{a}$ ). $\mathrm{N}_{\mathrm{ecl}}$ significantly decreased with an increase in control yield with an $R^{2}$ of 0.27 (Fig. 4b), and increased with increasing $\mathrm{N}$-derived yield with a higher $R^{2}$ of 0.83 (Fig. 4c). These results indicated that $\mathrm{N}_{\mathrm{ecl}}$ was primarily affected by the $\mathrm{N}$ derived yield.

\section{Discussion}

The efficient use of $\mathrm{N}$ fertilizer is essential to increasing the economic returns of maize production and minimizing the potential negative effects of $\mathrm{N}$ on soil, water, and air quality, especially in intensive agricultural systems (Chen et al., 2010). Current $\mathrm{N}$ management strategies have been aimed at determining regional $\mathrm{N}_{\text {eco }}$ to maximize profits (Scharf et al., 2005; Williams et al., 2007). For intensive maize systems on the NCP, $\mathrm{N}$ fertilizer application rates of $223-240 \mathrm{~kg} \mathrm{~N} \mathrm{ha}^{-1}$ have been recommended by government-supported extension services (Liu, 2009; Wang et al., 2012), which are similar to the $237 \mathrm{~kg} \mathrm{Nha}^{-1}$ found for $\mathrm{N}_{\text {eco }}$ in the present study.

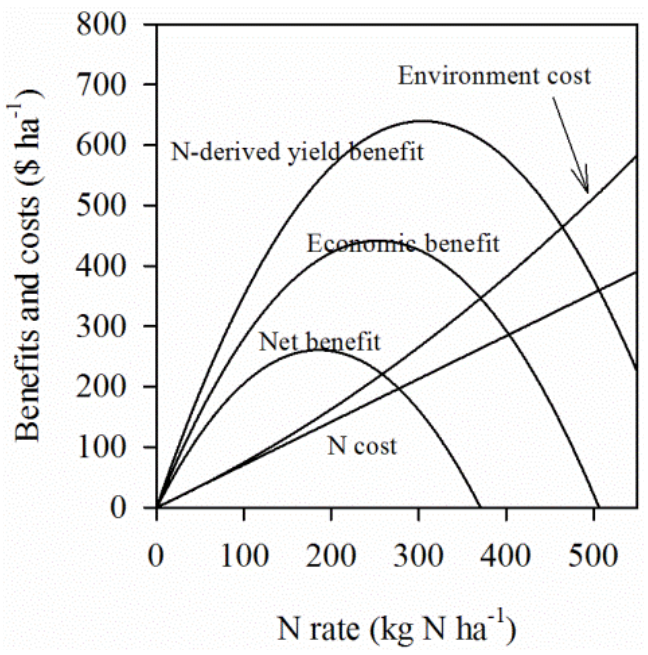

Figure 2. N-derived yield benefit, economic benefit, net benefit, $\mathrm{N}$ fertilizer cost, and environmental cost associated with different $\mathrm{N}$ rates over 91 sites in 12 counties in Henan Province for maize production in China from 2008 to 2009.

With $\mathrm{N}_{\text {eco }}$ management in this study, the grain yield averaged $8.5 \mathrm{Mg} \mathrm{ha}^{-1}$, and estimated $\mathrm{N}$ uptake was about $146 \mathrm{~kg} \mathrm{~N} \mathrm{ha}^{-1}$ (Yue, 2013), which is significantly lower than 


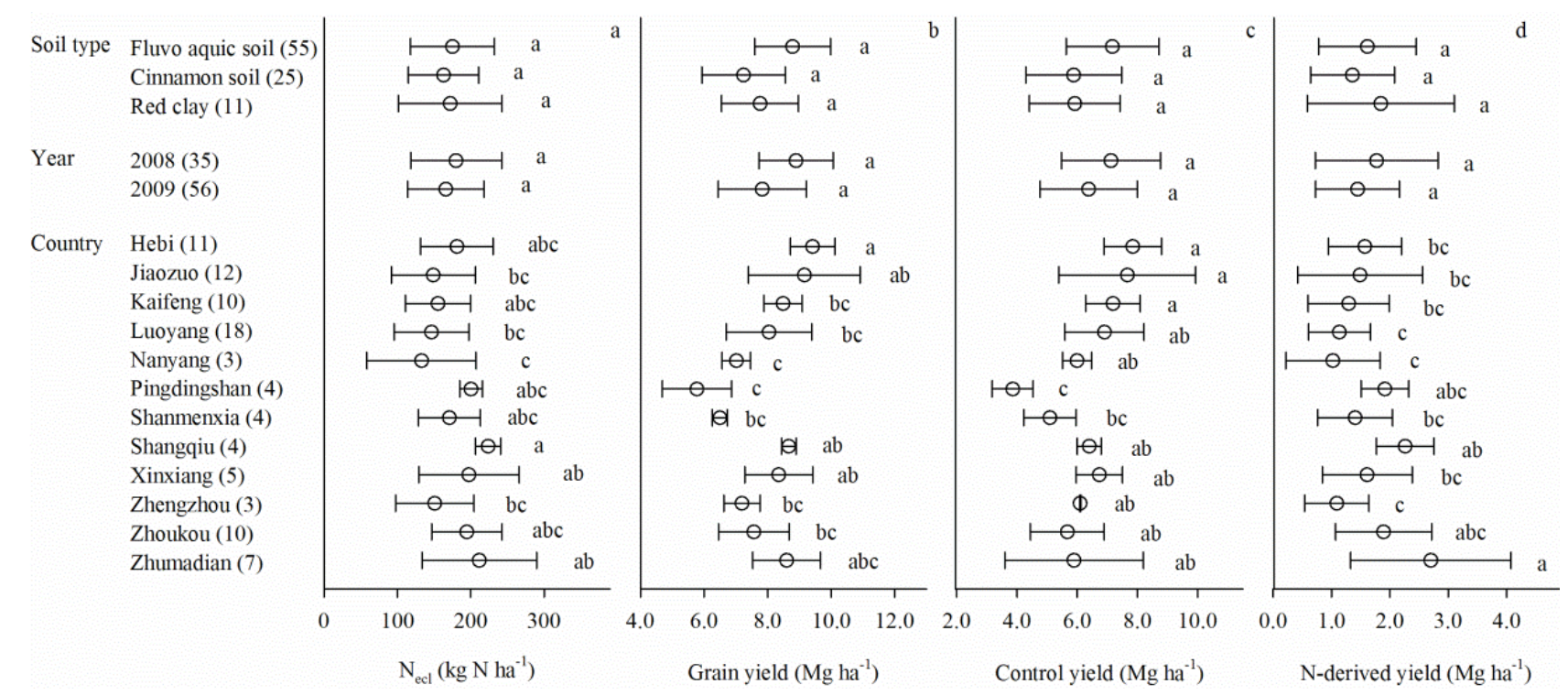

Figure 3. Average ecologically optimal $\mathrm{N}$ rate $\left(\mathrm{N}_{\mathrm{ecl}}\right)$ (a), grain yield (b), control yield (c), and $\mathrm{N}$-derived yield (d) when the data were examined by soil type, year, and county, respectively. Error bars indicate the standard deviations of the means of $\mathrm{N}_{\mathrm{ecl}}$, grain yield, control yield, and N-derived yield. Different letters to the right of data points indicate significant differences at $p<0.05$. The numbers of sites in each data group are given in parentheses.
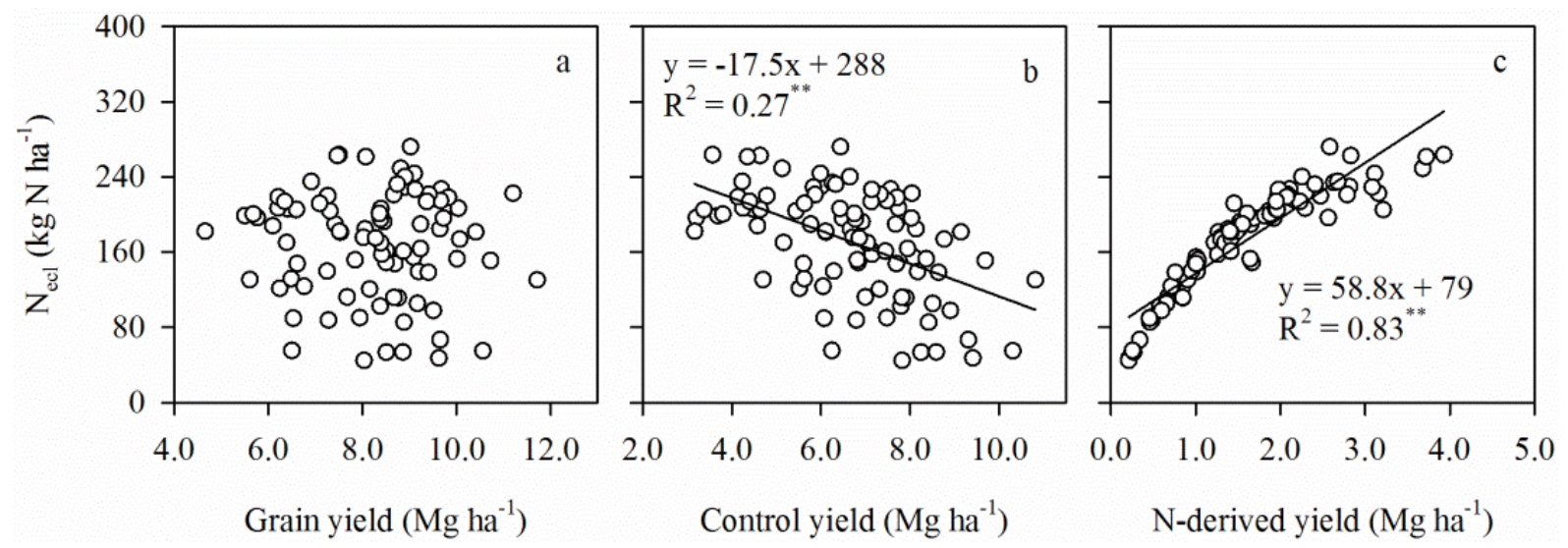

Figure 4. Relationships between the ecologically optimal $\mathrm{N}$ rate $\left(\mathrm{N}_{\mathrm{ecl}}\right)$ and grain yield (a), control yield (b), and $\mathrm{N}$-derived yield (c) over 91 sites in 12 counties in Henan Province for maize production in China from 2008 to 2009. ** Significant at $p<0.05$.

$237 \mathrm{~kg} \mathrm{Nha}^{-1}$ of the $\mathrm{N}_{\text {eco }}$ (Table 2). This large $\mathrm{N}$ surplus drives high $\mathrm{N}_{\mathrm{r}}$ losses and environmental pollution problems, such as the greenhouse effect, eutrophication, and soil acidification (Davidson, 2009; Guo et al., 2010; Ju et al., 2009; Reay et al., 2012; Zhang et al., 1996). These problems and their consequences are meaningful on a global scale.

For current intensive maize systems, when the greenhouse effect, eutrophication, and soil acidification associated with the $\mathrm{N}$ fertilizer production and use were considered, $\mathrm{N}_{\text {ecl }}$ was reduced by $28 \%$ to $171 \mathrm{~kg} \mathrm{Nha}^{-1}$, compared with the current $\mathrm{N}_{\text {eco }}$. As a result, this $\mathrm{N}_{\text {ecl }}$ management strategy reduced environment costs and $\mathrm{N}_{\mathrm{r}}$ loss intensity without significant decreases in grain yield or economic benefit. Similar results were reported for other cereal crop systems. Xia and Yan (2011a) used published field experiment measurements to establish grain yield and environmental cost response curves to the $\mathrm{N}$ application rate; they gave $\mathrm{N}_{\mathrm{ecl}}$ as $205 \mathrm{~kg} \mathrm{Nha}^{-1}$ for wheat production in the Taihu Lake region of China, which was $21 \%$ lower than the economically optimal $\mathrm{N}$ rate of $258 \mathrm{~kg} \mathrm{Nha}^{-1}$ and decreased $\mathrm{N}_{\mathrm{r}}$ losses by $28 \%$. For rice in the same region, the $\mathrm{N}_{\mathrm{ecl}}$ was $202 \mathrm{~kg} \mathrm{Nha}^{-1}, 23 \%$ lower than the economically optimal $\mathrm{N}$ rate of $263 \mathrm{~kg} \mathrm{~N} \mathrm{ha}^{-1}$, with a $29 \%$ decrease in $\mathrm{N}_{\mathrm{r}}$ losses (Xia and Yan, 2012).

Aside from the negative environmental effects, $\mathrm{N}$ application rates could also be optimized based on the concept of willingness to pay (WTP) for human health and ecosystem 
Table 2. $\mathrm{N}$ rate, grain yield, economic benefit, net benefit and environmental costs including global warming cost $\left(C_{\mathrm{gw}}\right)$, eutrophication cost $\left(C_{\text {eu }}\right)$ and acidification cost $\left(C_{\text {acid }}\right)$, with agronomically, economically, and ecologically optimal $\mathrm{N}$ rates, respectively, over 91 sites in 12 counties in Henan Province for maize production in China from 2008 to 2009. Different letters to the right of data indicate significant differences at $p<0.05$.

\begin{tabular}{|c|c|c|c|c|c|c|c|c|}
\hline \multirow[t]{2}{*}{ Item } & \multirow[t]{2}{*}{$\begin{array}{r}\mathrm{N} \text { rate } \\
\mathrm{kg} \mathrm{N} \mathrm{ha}^{-1}\end{array}$} & \multirow[t]{2}{*}{$\begin{array}{l}\text { Grain yield } \\
\mathrm{Mg} \mathrm{ha}^{-1}\end{array}$} & \multirow[t]{2}{*}{$\begin{array}{r}\text { Economic } \\
\text { benefit } \$ \mathrm{ha}^{-1}\end{array}$} & \multirow[t]{2}{*}{$\begin{array}{l}\text { Net benefit } \\
\qquad \text { ha }^{-1}\end{array}$} & \multicolumn{4}{|c|}{ Environmental costs $\left(\$ \mathrm{ha}^{-1}\right)$} \\
\hline & & & & & Total & $C_{\mathrm{gw}}$ & $C_{\mathrm{eu}}$ & $C_{\text {acid }}$ \\
\hline $\mathrm{N}_{\text {agr }}$ & $289^{\mathrm{a}}$ & $8.5^{\mathrm{a}}$ & $456^{\mathrm{a}}$ & $200^{\mathrm{b}}$ & $255^{\mathrm{a}}$ & $84^{\mathrm{a}}$ & $37^{\mathrm{a}}$ & $135^{\mathrm{a}}$ \\
\hline $\mathrm{N}_{\mathrm{eco}}$ & $237^{\mathrm{b}}$ & $8.5^{\mathrm{a}}$ & $474^{\mathrm{a}}$ & $273^{\mathrm{ab}}$ & $201^{b}$ & $66^{\mathrm{b}}$ & $26^{\mathrm{b}}$ & $109^{b}$ \\
\hline $\mathrm{N}_{\mathrm{ecl}}$ & $171^{\mathrm{c}}$ & $8.2^{\mathrm{a}}$ & $445^{\mathrm{a}}$ & $306^{\mathrm{a}}$ & $139^{c}$ & $45^{\mathrm{c}}$ & $16^{\mathrm{c}}$ & $77^{\mathrm{c}}$ \\
\hline
\end{tabular}

Table 3. $\mathrm{N}_{\mathrm{r}}$ loss intensity including $\mathrm{N}_{2} \mathrm{O}$ emission, $\mathrm{N}$ leaching and $\mathrm{NH}_{3}$ volatilization, from $\mathrm{N}$ fertilizer use with agronomically, economically, and ecologically optimal $\mathrm{N}$ rates, respectively, over 91 sites in 12 counties in Henan Province for maize production in China from 2008 to 2009. Different letters to the right of data indicate significant differences at $p<0.05$. $\mathrm{N}$ rate averaged 289, 237 and $171 \mathrm{~kg} \mathrm{Nha}^{-1}$, and the corresponding grain yields were $8.5,8.5$ and $8.2 \mathrm{~kg} \mathrm{Nha}^{-1}$, respectively.

\begin{tabular}{lrrrr}
\hline \multirow{2}{*}{ Item } & \multicolumn{3}{c}{$\mathrm{N}_{\mathrm{r}}$ loss intensity $\left(\mathrm{kg} \mathrm{N} \mathrm{Mg}^{-1}\right.$ grain) } \\
\cline { 2 - 5 } & Total & $\begin{array}{r}\mathrm{N}_{2} \mathrm{O} \\
\text { emission }\end{array}$ & $\begin{array}{r}\mathrm{N} \\
\text { leaching }\end{array}$ & $\begin{array}{r}\mathrm{NH}_{3} \\
\text { volatilization }\end{array}$ \\
\hline $\mathrm{N}_{\text {agr }}$ & $17.9^{\mathrm{a}}$ & $0.32^{\mathrm{a}}$ & $8.9^{\mathrm{a}}$ & $8.6^{\mathrm{a}}$ \\
$\mathrm{N}_{\text {eco }}$ & $13.0^{\mathrm{b}}$ & $0.24^{\mathrm{b}}$ & $5.6^{\mathrm{b}}$ & $7.1^{\mathrm{b}}$ \\
$\mathrm{N}_{\mathrm{ecl}}$ & $8.7^{\mathrm{c}}$ & $0.17^{\mathrm{c}}$ & $3.2^{\mathrm{c}}$ & $5.3^{\mathrm{c}}$ \\
\hline
\end{tabular}

services. Brink et al. (2011) estimated that excess $\mathrm{N}$ in the environment costs the European Union between 100 and 460 billion $\$$ per year, of which $\sim 75 \%$ is related to health damage and air pollution, and suggested that the socially optimal $\mathrm{N}$ rate would lower the farm (private) optimal $\mathrm{N}$ rate by $50 \mathrm{~kg} \mathrm{Nha}^{-1}\left(35-90 \mathrm{~kg} \mathrm{Nha}^{-1}\right)$ for winter wheat and oilseed rape. Another study based on life-cycle assessment showed a decrease in the optimal $\mathrm{N}$ rate of $50-100 \mathrm{~kg} \mathrm{~N} \mathrm{ha}^{-1}$ for winter wheat in the United Kingdom (Brentrup et al., 2004).

In the present study, the large variations in ecologically optimal $\mathrm{N}$ rates (from $45 \mathrm{~kg} \mathrm{Nha}^{-1}$ at site 14 in Luoyang County to $272 \mathrm{~kg} \mathrm{Nha}^{-1}$ at site 2 in Xinxiang County; Supplement Table 2) demonstrate the difficulties of ecological $\mathrm{N}$ management. Similar wide ranges in optimal $\mathrm{N}$ rates both among fields (Bundy and Andraski, 1995; Cui et al., 2008) and within fields (Mamo et al., 2003; Scharf et al., 2005) have been reported in other studies. In the present study, $\mathrm{N}_{\mathrm{ecl}}$ increased with increases in N-derived yield (Fig. $4 \mathrm{c}$ ), which was mostly associated with the high variability in farmers' practices. Similarly results were reported for spring maize systems in China (Gao et al., 2012). In the present study region, which represents a typical maize production area of China, each farmer operates on $<1$ ha of land. This small-scale farming with high variability between fields and poor infrastructure has reduced the efficiency of current science-based management tools and technological practices in China (Cui et al., 2010). Additionally, older and less-educated individuals frequently work in farming, and many educated young farmers have left the industry (Barning, 2008; Huang et al., 2008), which has been thought to contribute to the variation in farm practices. In the future, training and motivating farmers to improve crop management with increasing $\mathrm{N}$-derived yields would help to implement ecological $\mathrm{N}$ management.

Note that the present estimates of $\mathrm{N}_{\mathrm{ecl}}$ in this region (Supplement Table 2 and Table 2) are far from robust due to the uncertainties in estimating different $\mathrm{N}_{\mathrm{r}}$ losses from $\mathrm{N}$ fertilizer use, global warming potential of $\mathrm{N}$ fertilizer production, and the $\mathrm{N}$-derived yield benefit response to the $\mathrm{N}$ rate. In this study, $\mathrm{N}_{\mathrm{r}}$ losses from $\mathrm{N}$ fertilization use are expressed as a function of the $\mathrm{N}$ application rate, indicating that high $\mathrm{N}$ application rates always lead to large $\mathrm{N}_{\mathrm{r}}$ losses to the environment (Stehfest and Bouwman, 2006). However, $\mathrm{N}_{\mathrm{r}}$ losses also depend on some factors other than the $\mathrm{N}$ application rate, such as soil type, climate, and $\mathrm{N}$ application method (Gregorich et al., 2005). Cui et al. (2013b) indicated an appropriate source, timing, and placement of $\mathrm{N}$ fertilizer and related practices, which tend to enhance crop recovery of applied $\mathrm{N}$, increase crop yield, and could also contribute to lowering $\mathrm{N}_{\mathrm{r}}$ losses. Thus, environmental factors and crop practices affecting $\mathrm{N}_{\mathrm{r}}$ losses should be taken into account to minimize the uncertainty in regional estimations of $\mathrm{N}_{\mathrm{r}}$ losses.

In this study, $8.2 \mathrm{~kg} \mathrm{CO}_{2} \mathrm{eq} \mathrm{kg}^{-1}$ as an emission factor in $\mathrm{N}$ fertilizer production was introduced for estimating the global warming potential of $\mathrm{N}$ fertilizer production, and was variable among regions and within regions (Zhang et al., 2012). For example, global warming potential per unit $\mathrm{N}$ was on average $2.6 \mathrm{~kg} \mathrm{CO}_{2}$ eq in the US, only about one third of that in China (Grassini and Cassman, 2012; Zhang et al., 2012). The higher global warming potential from $N$ production per unit $\mathrm{N}$ in China was due to $86 \%$ of the energy consumed in the $\mathrm{N}$ fertilizer production based on coal, which had a low energy efficiency and greater global warming potential than other forms of energy such as natural gas (Zhang et al., 2012). 
The calculation of the impact on SOM degradation or soil $\mathrm{CO}_{2}$ emission associated with $\mathrm{N}$ fertilizer use was included in some studies other than the present one (Xiao and Xie, 2009; Yuan et al., 2011). Our study was conducted in a wheat-maize rotation system in the NCP, where straw returning has been widely applied in practice, and there is substantial replenishment of soil organic matter pools by straw returning, even without the application of manure. Many studies also showed that because of the increase in crop yield and the implementation of straw returning, soil organic matter content has been increasing in recent decades in this region (Xing and Han, 2007; Huang and Sun, 2006). Smith et al. (2007) indicated that the contribution of net $\mathrm{CO}_{2}$ released from soil to the greenhouse effect produced by agricultural production systems was lower than $1 \%$. In the future, the pursuit of higher grain yields indeed needs the integrated use of synthetic and organic $\mathrm{N}$ input to improve soil productivity with better soil structure and other soil quality aspects (Fan et al., 2011). Additional environmental costs because of the application of manure should then be included.

In addition, the volatile prices of maize yield, $\mathrm{N}$ fertilizer and various $\mathrm{N}_{\mathrm{r}}$ losses also affected the net benefit, and the estimated $\mathrm{N}_{\mathrm{ecl}}$ rate. When the price of maize increased from $360 \$ \mathrm{t}^{-1}$ in this study to $409 \$ \mathrm{t}^{-1}$ (the highest price in the last 10 years), the estimated $\mathrm{N}_{\mathrm{ecl}}$ only increased by $4 \%$ from 196 to $206 \mathrm{~kg} \mathrm{~N} \mathrm{ha}^{-1}$. Similarly, with the float of the prices of $\mathrm{N}$ fertilizer, environmental costs, there was little difference in $\mathrm{N}_{\mathrm{ecl}}$ (Supplement Table 3). Other studies also indicated that the optimal $\mathrm{N}$ rate is relatively insensitive to shifts in prices (Scharf et al., 2006; Chen et al., 2011).

In China, the typical small-scale farms with high variability between fields contributed to uncertainties in the regional estimation of the $\mathrm{N}$-derived yield benefit response to $\mathrm{N}$ rate. For example, within $210 \mathrm{~kg} \mathrm{~N} \mathrm{ha}^{-1}$, the N-derived yield benefit was $209 \$ \mathrm{ha}^{-1}$ at site 1 in Kaifeng County, compared with $1278 \$ \mathrm{ha}^{-1}$ at site 2 in Jiaozuo (Supplement Table 1). Therefore, more field experiment data sets should be obtained and a model considering environmental factors, fertilizer, and crop management systems should be used to determine regional $\mathrm{N}$-derived yield benefit and $\mathrm{N}_{\mathrm{r}}$ losses more accurately.

The goal of sustainable agriculture is to maximize the net benefits that society receives from agricultural production of food and from ecosystem services (Tilman et al., 2002). This will require increased crop yield, increased efficiency of nutrient and water use, improved soil quality, ecologically based management practice, judicious use of pesticides and antibiotics, and adapting of cropping systems to climate change. Advances in the fundamental understanding of the agricultural food environment system's complex linkage on local and regional scales can contribute greatly to sustainability.

\section{Conclusions}

A marked increase in $\mathrm{N}$ fertilizer consumption is expected to occur worldwide within a few years because of the growing demand for crop production. As demonstrated in this study, the $\mathrm{N}$ application rate is an important factor affecting both the economic and environmental performance of corn production. Applying an appropriate $\mathrm{N}$ rate could both enhance farm profitability and reduce the $\mathrm{N}_{\mathrm{r}}$ losses associated with maize yield. In our study, the $\mathrm{N}_{\mathrm{ecl}}$ averaged $171 \mathrm{~kg} \mathrm{Nha}^{-1}$ across 91 on-farm experimental sites. This ecological $\mathrm{N}$ management had the highest net benefit of $306 \$ \mathrm{ha}^{-1}$, reduced $\mathrm{N}$ rate and total environmental costs by 28 and $31 \%$, and $\mathrm{N}_{\mathrm{r}}$ loss intensity by $33 \%$, including 29,44 , and $25 \%$ for $\mathrm{N}_{2} \mathrm{O}$ emission, $\mathrm{N}$ leaching, and $\mathrm{NH}_{3}$ volatilization, respectively, without significant decreases in grain yield as compared with the $\mathrm{N}_{\text {eco }}$ of $237 \mathrm{~kg} \mathrm{Nha}^{-1}$.

The $\mathrm{N}_{\mathrm{ecl}}$ varied with farming site. The typical small farms with high variability in farming practices resulted in variations in $\mathrm{N}_{\mathrm{ecl}}$ from 45 to $272 \mathrm{~kg} \mathrm{Nha}^{-1}$. To determine a regional $\mathrm{N}_{\mathrm{ecl}}$, models considering environmental factors, fertilizer, and crop management strategies should be used to estimate $\mathrm{N}_{\mathrm{r}}$ losses accurately, and more field experiment data sets should be obtained to determine the yield benefit responses to the $\mathrm{N}$ application rate. In the future, increases in $\mathrm{N}$-derived yield will be important to demonstrate this ecological $\mathrm{N}$ management, and training and motivating farmers to use improved techniques will be essential steps.

\section{The Supplement related to this article is available online at doi:10.5194/bg-11-3031-2014-supplement.}

Acknowledgements. This work was funded by the Special Fund for the Agricultural Profession (201303103), National Natural Science Foundation of China (31172036), the Program for New Century Excellent Talents in University (NCET-11-0478), and the Innovation Group Grant of the National Natural Science Foundation of China (31121062).

Edited by: A. Neftel

\section{References}

Barning, R.: Economic evaluation of nitrogen application in the North China Plain, Ph.D. thesis, Hohenheim University, Stuttgart, Germany, 2008

Brentrup, F., Küsters, J., Lammel, J., Barraclough, P., and Kuhlmann, H.: Environmental impact assessment of agricultural production systems using the life cycle assessment (LCA) methodology II. The application to $\mathrm{N}$ fertilizer use in winter wheat production systems, Eur. J. Agron., 20, 265-279, 2004.

Brink, C., van Grinsven, H., Jakobsen, B. H., Rabl, A., Gren, I. M., Holland, M., Klimont, Z., Hicks, K., Brouwer, R., Dickens, 
R., Willems, J., Termansen, M., Velthof, G., Alkemade, R., van Oorschot, M., and Webb, J.: Costs and benefits of nitrogen in the environment, in: The european nitrogen assessment - sources, effects and policy perspectives, edited by: Sutton, M. A., Howard, C. M., Erisman, J. W., Billen, G., Bleeker, A., Grennfelt, P., van Grinsven, H., and Grizzetti, B., Cambridge University Press, Cambridge, 513-540, 2011.

Bullock, D. G. and Bullock, D. S.: Quadratic and quadratic-plusplateau models for predicting optimal nitrogen rate of corn: A comparison, Agron. J., 86, 191-195, 1994.

Bundy, L. and Andraski, T.: Soil yield potential effects on performance of soil nitrate tests, J. Prod. Agric., 8, 561-568, 1995.

Cassman, K. and Plant, R.: A model to predict crop response to applied fertilizer nutrients in heterogeneous fields, Fert. Res., 31, 151-163, 1992.

Cassman, K. G. and Pingali, P. L.: Extrapolating trends from long term experiments to farmers' field: The case of irrigated rice sytems in Asia, in: Agricultural sustainability: economic, environmental and sustainable considerations, edited by: Burnett, V., Payne, R., and Steiner, R., John Wiley and Sons, London, 63-84, 1995.

Cassman, K. G., Dobermann, A., and Walters, D. T.: Agroecosystems, nitrogen-use efficiency, and nitrogen management, Ambio, 31, 132-140, 2002.

Cassman, K. G., Dobermann, A., Walters, D. T., and Yang, H.: Meeting cerea ldemand while protecting natural resources and improving environmental quality, Annu. Rev. Env. Resour., 28, 315-358, 2003.

Chen, J., Huang, Y., Tang, Y.: Quantifying economically and ecologically optimum nitrogen rates for rice production in southeastern China, Agri. Ecosys. Envir., 142, 195-204, 2011.

Chen, X., Zhang, F., Cui, Z., Li, J., Ye, Y., and Yang, Z.: Critical grain and stover nitrogen concentrations at harvest for summer maize production in China, Agron. J., 102, 289-295, 2010.

Cui, Z., Chen, X., Miao, Y., Zhang, F., Sun, Q., Schroder, J., Zhang, H., Li, J., Shi, L., and Xu, J.: On-Farm Evaluation of the Improved Soil N-based Nitrogen Management for Summer Maize in North China Plain, Agron. J., 100, 517-525, 2008.

Cui, Z., Chen, X., and Zhang, F.: Current nitrogen management status and measures to improve the intensive wheat-maize system in China, Ambio, 39, 376-384, 2010.

Cui, Z., Yue, S., Wang, G., Meng, Q., Wu, L., Yang, Z., Zhang, Q., Li, S., Zhang, F., and Chen, X.: Closing the yield gap could reduce projected greenhouse gas emissions: a case study of maize production in China, Glob. Change Biol., 19, 2467-2477, doi:10.1111/gcb.12213, 2013a.

Cui, Z., Yue, S., Wang, G., Zhang, F., and Chen, X.: In-season rootzone $\mathrm{N}$ management for mitigating greenhouse gas emission and reactive $\mathrm{N}$ losses in intensive wheat production, Environ. Sci. Technol., 47, 6015-6022, 2013b.

Cui, Z. L., Xu, J. F., Shi, L. W., Chen, X. P., Zhang, F. S., and Li, J. L.: Field quick testing method of soil nitrate, J. China Agr. Univ., 10, 10-12, 2005.

Davidson, E. A.: The contribution of manure and fertilizer nitrogen to atmospheric nitrous oxide since 1860, Nat. Geosci., 2, 659662, 2009.

Dobermann, A., Dawe, D., Roetter, R. P., and Cassman, K. G.: Reversal of rice yield decline in a long-term continuous cropping experiment, Agron. J., 92, 633-643, 2000.
Drinkwater, L. E. and Snapp, S.: Nutrients in agroecosystems: rethinking the management paradigm, Adv. Agron., 92, 163-186, 2007.

Fan, M. S., Shen, J. B., Yuan, L. X., Jiang, R. F., Chen, X. P., Davies, W., and Zhang, F. S.: Improving crop productivity and resource use efficiency to ensure food security and environmental quality in China, J. Exp. Bot., 63, 13-24, 2012.

Forster, P., Ramaswamy, V., Artaxo, P., Berntsen, T., Betts, R., Fahey, D. W., Haywood, J., Lean, J., Lowe, D. C., Myhre, G., Nganga, J., Prinn, R., Raga, G., Schulz, M., and Dorland, R. V.: Changes in atmospheric constituents and in radiative forcing, in: Climate Change 2007: The physical science basis. Contribution of working group I to the fourth assessment report of the Intergovernmental panel on climate change, edited by: Solomon, S., Qin, D., Manning, M., Chen, Z., Marquis, M., Averyt, K. B., Tignor, M., and Miller, H. L., Cambridge University Press, 129-234, 2007

Galloway, J. N., Dentener, F. J., Capone, D. G., Boyer, E. W., Howarth, R. W., Seitzinger, S. P., Asner, G. P., Cleveland, C., Green, P., and Holland, E.: Nitrogen cycles: past, present, and future, Biogeochemistry, 70, 153-226, 2004.

Gao, Q., Li, C., Feng, G., Wang, J., Cui, Z., Chen, X., and Zhang, F.: Understanding yield response to nitrogen to achieve high yield and high nitrogen use efficiency in rainfed corn, Agron. J., 104, 165-168, 2012.

Goedkoop, M.: The eco-indicator 95: weighting method for environmental impact analysis for clean design, Comput. Chem. Eng., 20, 1377-1382, 1995.

Grassini, P. and Cassman, K. G.: High-yield maize with large net energy yield and small global warming intensity, P. Natl. Acad. Sci., 109, 1074-1079, 2012.

Gregorich, E., Rochette, P., VandenBygaart, A., and Angers, D.: Greenhouse gas contributions of agricultural soils and potential mitigation practices in Eastern Canada, Soil Till. Res., 83, 53-72, 2005.

Guarda, G., Padovan, S., and Delogu, G.: Grain yield, nitrogen-use efficiency and baking quality of old and modern Italian breadwheat cultivars grown at different nitrogen levels, Eur. J. Agron., 21, 181-192, 2004.

Guo, J., Liu, X., Zhang, Y., Shen, J., Han, W., Zhang, W., Christie, P., Goulding, K., Vitousek, P., and Zhang, F.: Significant acidification in major Chinese croplands, Science, 327, 1008-1010, 2010.

Huang, J., Hu, R., Cao, J., and Rozelle, S.: Training programs and in-the-field guidance to reduce China's overuse of fertilizer without hurting profitability, J. Soil Water Conserv., 63, 165-167, 2008.

Huang, Y and Sun, W. J.: The changes of soil organic carbon content of farmland surfance in China in the last 20 years, Chin. Sci. Bull., 51, 750-763, 2006.

$\mathrm{Ju}, \mathrm{X}$. and Christie, P.: Calculation of theoretical nitrogen rate for simple nitrogen recommendations in intensive cropping systems: A case study on the North China Plain, Field Crop. Res., 124, 450-458, 2011.

Ju, X. T., Xing, G. X., Chen, X. P., Zhang, S. L., Zhang, L. J., Liu, X. J., Cui, Z. L., Yin, B., Christie, P., and Zhu, Z. L.: Reducing environmental risk by improving $\mathrm{N}$ management in intensive Chinese agricultural systems, P. Natl. Acad. Sci., 106, 3041-3046, 2009. 
Kim, D. G., Hernandez-Ramirez, G., and Giltrap, D.: Linear and nonlinear dependency of direct nitrous oxide emissions on fertilizer nitrogen input: A meta-analysis, Agr. Ecosyst. Environ., 168, 53-65, 2013.

Liang, X., Li, H., He, M., Chen, Y., Tian, G., and Xu, S.: The ecologically optimum application of nitrogen in wheat season of rice-wheat cropping system, Agron. J., 100, 67-72, 2008.

Liu, C. A., Zhou, L. M., Jia, J. J., Wang, L. J., Si, J. T., Li, X., Pan, C. C., Siddique, K. H. M., and Li, F.-M.: Maize yield and water balance is affected by nitrogen application in a film-mulching ridgefurrow system in a semiarid region of China, Eur. J. Agron., 52, 103-111, 2014.

Liu, M., Du, L., and Zhang, X.: Farmers' willingness on organic fertilizer application based on logit model and influencing factors, J. Anhui Agr. Sci., 38, 4827-4829, 2010.

Liu, Z. P.: Enhancing technology diffusion of soil testing and fertilizer recommendation in Henan province in the fall of 2009, Agriculture of Henan, 8, p. 31, 2009.

Mamo, M., Malzer, G., Mulla, D., Huggins, D., and Strock, J.: Spatial and temporal variation in economically optimum nitrogen rate for corn, Agron. J., 95, 958-964, 2003.

McSwiney, C. P. and Robertson, G. P.: Nonlinear response of $\mathrm{N}_{2} \mathrm{O}$ flux to incremental fertilizer addition in a continuous maize (Zea mays L.) cropping system, Glob. Change Biol., 11, 1712-1719, 2005.

Meng, Q.-F., Chen, X.-P., Zhang, F.-S., Cao, M.-H., Cui, Z.-L., Bai, J.-S., Yue, S.-C., Chen, S.-Y., and Müller, T.: In-Season RootZone Nitrogen Management Strategies for Improving Nitrogen Use Efficiency in High-Yielding Maize Production in China, Pedosphere, 22, 294-303, 2012.

Moomaw, W. R. and Birch, M. B.: Cascading costs: An economic nitrogen cycle, Sci. China Ser. C, 48, 678-696, 2005.

Neeteson, J. and Wadman, W.: Assessment of economically optimum application rates of fertilizer $\mathrm{N}$ on the basis of response curves, Fert. Res., 12, 37-52, 1987.

Raun, W. R. and Johnson, G. V.: Improving nitrogen use efficiency for cereal production, Agron. J., 91, 357-363, 1999.

Reay, D. S., Davidson, E. A., Smith, K. A., Smith, P., Melillo, J. M., Dentener, F., and Crutzen, P. J.: Global agriculture and nitrous oxide emissions, Nat. Clim. Change, 2, 410-416, 2012.

Sawyer, J., Nafziger, E., Randall, G., Bundy, L., Rehm, G., and Joern, B.: Concepts and rationale for regional nitrogen rate guidelines for corn, Iowa State University, University Extension, available at: https://store.extension.iastate.edu/Product/pm2015-pdf (last access: 14 February 2014), 2006.

Scharf, P. C., Kitchen, N. R., Sudduth, K. A., Davis, J. G., Hubbard, V. C., and Lory, J. A.: Field-scale variability in optimal nitrogen fertilizer rate for corn, Agron. J., 97, 452-461, 2005.

Scharf, P. C., Kitchen, N. R., Sudduth, K. A., and Davis, J. G.: Spatially variable corn yield is a weak predictor of optimal nitrogen rate, Soil Sci. Soc. Am. J. 70, 2154-2160, 2006.

Smith, P., Martino, D., Cai, Z., Gwary, D., Janzen, H., Kumar, P., McCarl, B., Ogle, S., Mara, F.O., Rice, C., Scholes, B., Sirotenko, O.: Agriculture, 2007, in: Climate Change 2007: Mitigation, edited by: Metz, B., Davidson, O. R., Bosch, P. R., Dave, R., and Meyer, L. A., Contribution of Working Group III to the Fourth Assessment Report of the Intergovernmental Panel on Climate Change, Cambridge University Press, Cambridge, United Kingdom and New York, NY, USA.
Stehfest, E. and Bouwman, L.: $\mathrm{N}_{2} \mathrm{O}$ and $\mathrm{NO}$ emission from agricultural fields and soils under natural vegetation: summarizing available measurement data and modeling of global annual emissions, Nutr. Cycl. Agroecosys., 74, 207-228, 2006.

Tilman, D., Fargione, J., Wolff, B., D’Antonio, C., Dobson, A., Howarth, R., Schindler, D., Schlesinger, W. H., Simberloff, D., and Swackhamer, D.: Forecasting agriculturally driven global environmental change, Science, 292, 281-284, 2001.

Tilman, D., Cassman, K. G., Matson, P. A., Naylor, R., Polasky, S.: Agricultural sustainability and intensive production practices, Nature, 418, 671-677, 2002.

Tilman, D., Balzer, C., Hill, J., and Befort, B. L.: Global food demand and the sustainable intensification of agriculture, P. Natl. Acad. Sci., 108, 20260-20264, 2011.

Wang, S. J., Han, K. L., Li, Q., and Chen, H. J.: The optimum amount of nitrogen fertilizer of maize in Jianghuai area, Chinese Agr. Sci. Bull., 29, 47-50, 2013.

Wang, Y. L., Miao, Y. X., Gui, H. P., Su, R. G., and Tan, J. F.: Effect of recommend fertilization on summer maize in different soil groups, J. Agr. Sci. Technol., 14, 110-115, 2012.

Williams, J. D., Crozier, C. R., White, J. G., Heiniger, R. W., Sripada, R. P., and Crouse, D. A.: Illinois soil nitrogen test predicts southeastern US corn economic optimum nitrogen rates, Soil Sci. Soc. Am. J., 71, 735-744, 2007.

Xia, Y. and Yan, X.: Comparison of statistical models for predicting cost effective nitrogen rate at rice-wheat cropping systems, Soil Sci. Plant Nutr., 57, 320-330, 2011 a.

Xia, Y. Q. and Yan, X. Y.: Nitrogen fertilization rate recommendation integrating agronomic, environmental, and economic benefits for wheat season in the Taihu Lake region, Acta Pedologica Sinica, 48, 1210-1218, 2011b.

Xia, Y. and Yan, X.: Ecologically optimal nitrogen application rates for rice cropping in the Taihu Lake region of China, Sustain. Sci., 7, 33-44, 2012.

Xiao, Y. and Xie, G. D.: Comprehensive valuation of the ecosystem services of rice paddies in Shanghai, Resour. Sci, 31, 38-47, 2009.

Xing, S. and Han, B.: Study for ways of fertilizing soil in wheatcorn rotation system in North China Plain, Chinese J. Soil Sci., 38, 1013-1015, 2007.

Ye, Y., Wang, G., Huang, Y., Zhu, Y., Meng, Q., Chen, X., Zhang, F., and Cui, Z.: Understanding physiological processes associated with yield-trait relationships in modern wheat varieties, Field Crop. Res., 124, 316-322, 2011.

Yuan, Y., Liu, J. T., and Jin, Z. Z.: An integrated assessment of positive and negative effects of high-yielding cropland ecosystem services in Luancheng County, Hebei Province of North China, Chinese J. Ecol., 30, 2809-2814, 2011.

Yue, S. C.: Optimum nitrogen management for high-yielding wheat and maize cropping system, Ph.D. thesis, China Agricultural University, 2013.

Zhang, F. R.: Soil geography, China Agriculture Press, 2002.

Zhang, W., Tian, Z., Zhang, N., and Li, X.: Nitrate pollution of groundwater in northern China, Agr. Ecosyst. Environ., 59, 223231, 1996.

Zhang, W. F., Dou, Z, X., He, P., Ju, X. T., Powlson, D., Chadwick, D., Norse, D., Lu, Y. L., Zhang, Y., Wu, L., Chen, X. P., Cassman, K. G., Zhang, F. S.: New technologies reduce greenhouse 
gas emissions from nitrogenous fertilizer in China, P. Natl. Acad. Sci., 110, 8375-8380, 2012.

Zhang, W. F., Ma, L., Huang, G. Q., Wu, L., Chen, X., Zhang, F.: The development and contribution of nitrogenous fertilizer in china and challenges faced by the Country, Scientia Agricultura Sinica, 46, 3161-3171, 2013.
Zhu, Z.: On the methodology of recommendation for the application rate of chemical fertilizer nitrogen to crops, Plant Nutr. Fert. Sci., $12,1-4,2006$.

Zhu, Z. and Chen, D.: Nitrogen fertilizer use in ChinaContributions to food production, impacts on the environment and best management strategies, Nutr. Cycl. Agroecosys., 63, 117-127, 2002. 